УдК 330.3

O. Nazarenko,

Doctor of Economic Sciences, Professor of the Department

of Accounting and Taxation, Sumy National Agrarian University, Sumy

ORCID ID: 0000-0001-7546-174X

Hailiang Zhong,

Master's degree student, Sumy National Agrarian University, Sumy

ORCID ID: 0000-0002-7245-4189

DOI: $10.32702 / 2306-6814.2020 .19-20.40$

\title{
THE IMPACT OF THE DEVELOPMENT OF THE DIGITAL ECONOMY ON RETAIL TRADE ENTERPRISES IN CHINA
}

\author{
О. В. Назаренко, \\ А. е. н., професор, професор кафедри обліку і оподаткування, \\ Сумський національний аграрний університет, м. Суми \\ Хайлянь Ажун, \\ магістрант, Сумський національний аграрний університет, Суми
}

\section{ВП ИВ РОЗВИТКУ ЦИФРОВОЇ ЕКОНОМІКИ НА РОЗАРІБНІ ТОРГОВІ ПІАПРИЕМСТВА В КИТА ̈I}

After the international financial crisis, the world economy has entered a new stage of profound transformation. Against the backdrop of global penetration, cross-border integration, accelerated innovation and priority development, China's digital economy has made significant progress. High innovation of the digital economy will accelerate the penetration and integration of related industries, will form new models and new forms of business, will help optimize the structural structure of the economy of a country and the world.

Retail is the closest commercial form of human livelihood, is an important driver of economic growth. In recent years, thanks to the rapid popularization of the mobile Internet, access to large data sets and other new technologies, retail has grown rapidly. This research examines the relationship, features of operation, and prospects for the development of the digital economy and retail in China.

New models, forms of business, such as Internet road transport, e-commerce, Internet finance and intelligent logistics, have been formed to promote the development of services. Under the influence of the Internet, retail trade has undergone great changes: the convenience and intelligence of retail terminals have been improved, and the variety of retail services has been enriched.

The Research Development Institute identifies six aspects of China's digital economy development: infrastructure, integrated programs, enterprise transformation, public administration transformation, regional development and digital governance.

E-commerce companies should be encouraged to develop their own brand, strengthen cooperation with traditional retailers, which already have their own permanent reputation, a well-known brand. At the same time, appropriate platforms for business expansion in rural areas and international markets should be supported. In China, in today's business environment, the digitalization of the economy is the main vector of movement. Many relevant measures have been implemented in the country, especially in the retail sector, which require scientific support in the future.

Після міжнародної фінансової кризи світова економіка вступила в новий етап глибоких перетворень. На тлі глобального проникнення, транскордонної інтеграції, прискорених інновацій та пріоритетного розвитку, цифрова економіка Китаю досягла значного прогресу. Висока інно- 
ваційність зазначеної галузі прискорить проникнення та інтеграцію пов 'язаних з нею галузей, сформує нові моделі та нові форми бізнесу, сприятиме оптимізації структурної побудови економіки окремої країни та світу.

Роздрібна торгівля виступає найбільш близькою до засобів фізичного існування людей комерційною формою, є важливою рушійною силою економічного зростання. В останні роки, завдяки швидкій популяризації мобільного інтернету, доступудо великих масивів даних та інших нових технологій, роздрібна торгівля досягла бурхливого розвитку. У цій науковій роботі досліджено взаємозв'язок, особливості функціонування та перспективи розвитку цифрової економіки та роздрібної торгівлі в Китаї.

Нові моделі, форми бізнесу, як-от: інтернет-автомобільні перевезення, електронна комерція, інтернет-фінанси та інтелектуальна логістика, були сформовані для сприяння розвитку сфери послуг. Під впливом інтернету роздрібна торгівля зазнала великих змін: покращено зручність та інтелект терміналів роздрібної торгівлі, збагачено різноманітність роздрібних послуг.

Інститут розвитку досліджень, ідентифікує шість аспектів розвитку цифрової економіки Китаю: інфраструктура, інтегровані програми, трансформація підприємств, трансформація державних органів управління, регіональний розвиток та цифрове управління.

Підприємства електронної комерції слід заохочувати до розвиткувласного бренду, посилення співпраці з традиційними роздрібними підприємствами, які вже мають власну сталу репутацію, відому торгову марку. Одночасно слід підтримати відповідні платформи для розширення бізнесу на сільських територіях та міжнародних ринках. В Китаї, за сучасних бізнес умов, цифровізація економіки виступає основним вектором руху. В країні запроваджено багато відповідних заходів, особливо в секторі роздрібної торгівлі, які вимагають наукового супроводження у майбутньому.

Key word: economy, innovation, internet trade, retail trade, digital economy.

Ключові слова: економіка, інновачія, інтернет торгіВля, роздрібна торгівля, цифрова економіка.

\section{PROBLEM STATEMENT IN GENERAL FORM}

The modern information technology revolution represented by computer, network and communication has given birth to the digital economy. At present, digital technology is being widely used in modern economic activities, improving economic efficiency and accelerating the transformation of economic structure. It is becoming an important driving force for global economic recovery. For China, the digital economy is not only a new variable for economic transformation and growth, but also a new blue ocean for improving the quality and efficiency of the economy. We need to seize the new historical opportunity, foster new growth drivers through informatization, and use new growth drivers to promote new development. We need to make the digital economy bigger and stronger, and open up new space for economic development.

After the international financial crisis, the global economy has entered a new stage of profound adjustment. The picture of the old economy changing hands is both dramatic and gripping: traditional economies remain in the doldrums while the digital economy takes off. China's experience confirms this process and makes this picture more visible. Against the backdrop of global it penetration, cross-border integration, accelerated innovation and led a new stage of development, China's digital economy has made considerable progress. It is becoming a strong driving force for innovative economic development and will continue to accumulate experience for global economic recovery and social progress.
Retail industry is the main industry of circulation industry, is the most close to the people's livelihood of the commercial form, is an important driving force for economic growth. In recent years, with the rapid popularization of mobile Internet, big data and other emerging technologies, the retail industry has achieved a booming development. This paper will discuss the impact of the digital economy era on the retail industry.

\section{IDENTIFY PREVIOUSLY UNRESOLVED PART OF THE PROBLEM}

First, the market continues to expand. In 2018, the total retail sales of consumer goods nationwide reached 38.1 trillion yuan, an increase of $9 \%$ over the same period last year. Beijing achieved a total consumption of 2.54 trillion yuan, with a year-on-year growth of $7.4 \%$. The city's total consumption exceeded 2 trillion yuan for two consecutive years, setting a new high in scale.

Statistics from the Ministry of Industry and Information Technology show that by the end of 2018 , the value-added of China's large-scale electronic information manufacturing industry had increased by 13.1 percent year on year, and the national online retail sales had exceeded 9 trillion yuan, up by 23.9 percent year on year. According to a CNNIC report, as of June 2018, the number of Internet users in China has reached 802 million, including 788 million mobile phone users. By September 2018, three Chinese companies were among the top 10 listed Internet companies in terms of market capitalization, and nine were among the top 20 in 
The development of China's digital economy

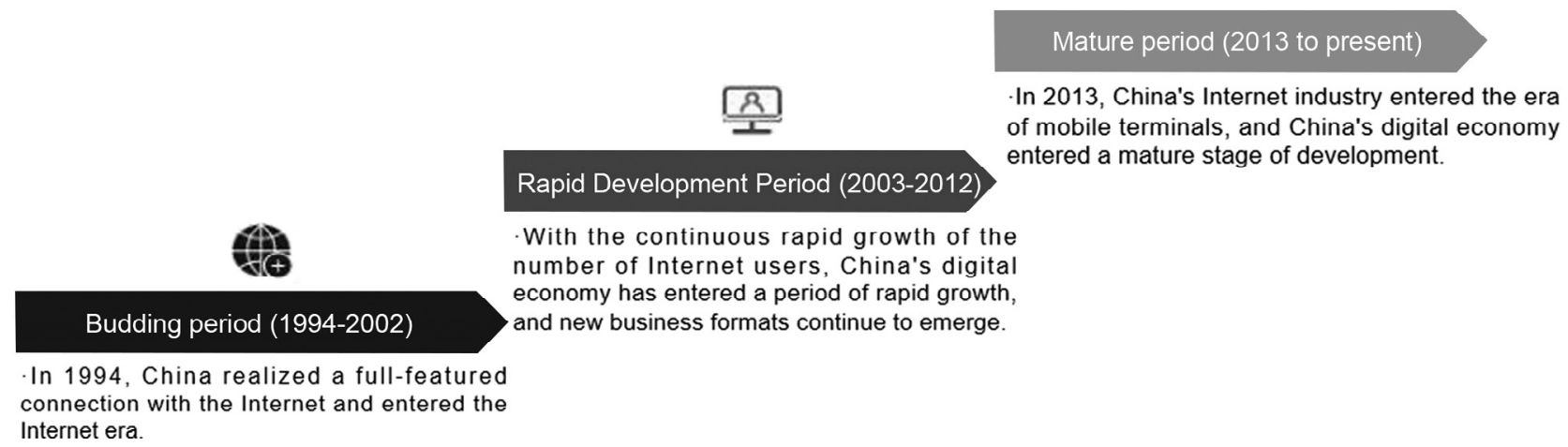

Figure 1. The development of China's digital economy

Data from: http://cpc.people.com.cn/

the world. On the other hand, the continuous integration of the digital economy and traditional industries has overturned and reshaped the old economic model, promoted the optimization and upgrading of industrial structure, and given birth to a series of new business forms and models. Statistics show that by the end of 2018 , the number of users of online taxi booking and online government services alone had exceeded 100 million [1].

In 1994, China was fully connected to the Internet and entered the Internet era. Around 2000, the global Internet bubble burst and the industry experienced a $2-3$ year downturn, with China also not immune. After a short downturn, with the continuous rapid growth of the number of Internet users, China's digital economy ushered in a period of rapid growth from 2003 to 2012, with the emergence of new forms of business. By the end of 2012, the number of Mobile phone users in China had reached 420 million, surpassing desktop computers for the first time as the number one terminal for accessing the Internet, indicating that China's digital economy has entered a new stage of development. In 2013, China's Internet industry entered the era of mobile terminals, and China's digital economy entered the mature stage. As shown in figure 1.

\section{THE PURPOSES FORMATION \\ OF THE ARTICLE}

Based on the frontier perspective of digital economy, it is of practical significance in three aspects to understand the industrial status quo of basic industries and retail industry of digital economy and analyse the impact on retail industry under the background of digital economy [2]. Firstly, the research on the basic industry of digital economy and the retail industry can provide research support for the establishment of an industrial structure with complementary advantages and reasonable division of labor and an industrial system that promotes each other. Second, in the next few years is deepening reform in our country, accelerate transformation of the mode of economic development of Gong Jian Qi, under the trend of the global digital economy, how to lead the digital economy foundation industry smooth fusion and successful integration with other industries, especially smooth integration with the traditional retail, can realize leap-forward development for China's retail industry and driving the development of its economic transformation has important significance; Thirdly, the transformation and upgrading of retail industry under the background of digital

2005-2019 China's digital economy added value scale and proportion of GDP (unit: 100 million yuan, \%)
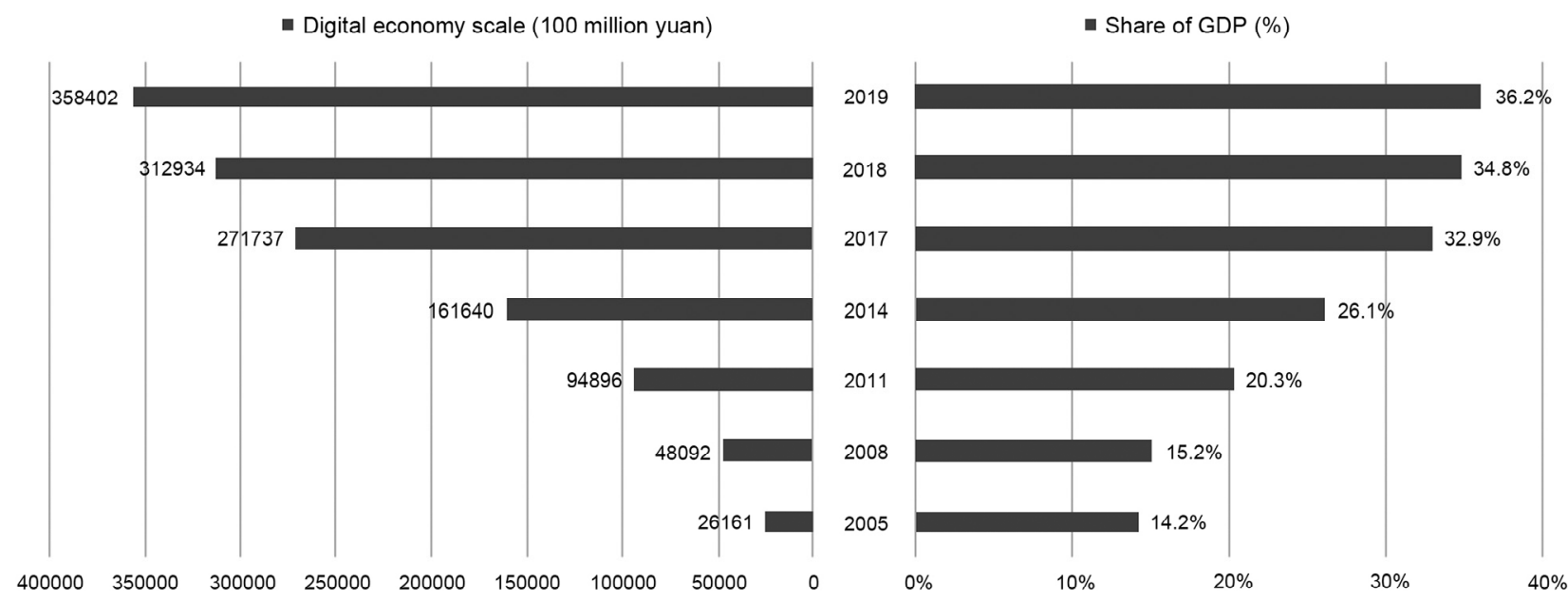

Figure 2. The scale of Digital Eva in China and its proportion in GDP from may to 2019

Data from: China Academy of Information and Communications Technology. 


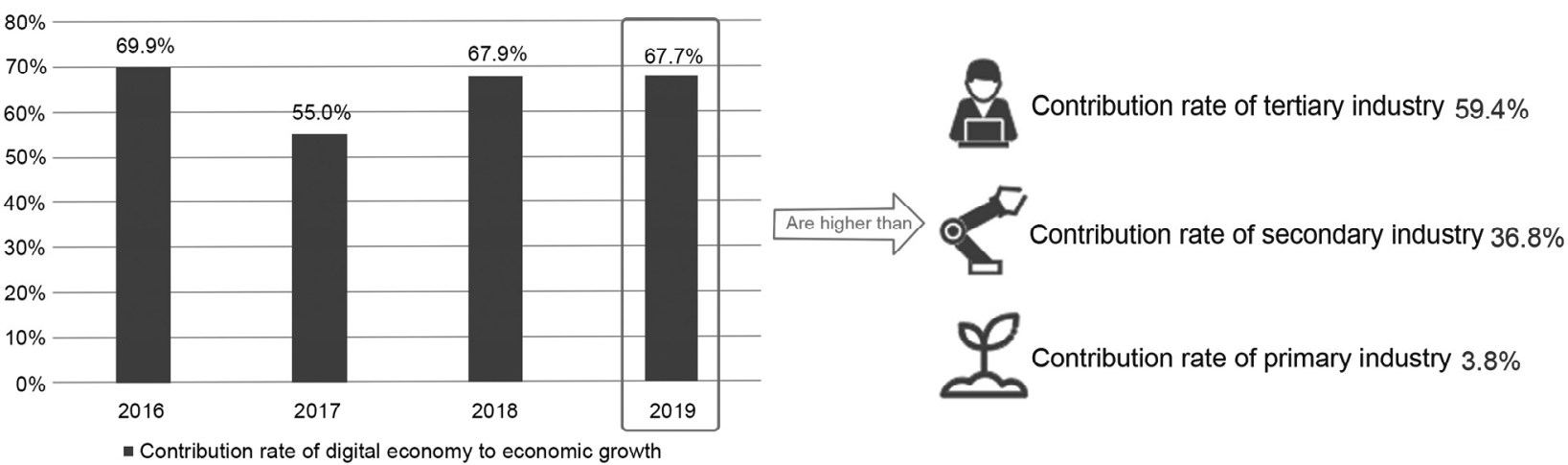

Figure 3. 2016-2019 Contribution of digital economy to Economic growth in China

Data from: China Academy of Information and Communications Technology.

economy will inevitably be accompanied by many problems and challenges in its development process. This paper expects to provide scientific reference for responding to the challenges brought by industrial upgrading and provide reference basis for government departments and industry management organizations to make policies.

\section{PRESENTING THE MAIN MATERIAL}

In recent years, digital economy has become a new driving force for high-quality development of China's national economy. The scale of digital Added value of economy has increased from 2.6 trillion yuan in 2005 to 35.8 trillion yuan in 2019 . At the same time, the proportion of digital economy in THE DGP has been increasing year by year, from $14.2 \%$ in 2005 to $36.2 \%$ in 2019 . As shown in figure 2.

Depending on its high innovation and strong permeability, the digital economy industry will accelerate the penetration and integration into its related industries, form new models and new forms of business, and thus promote the adjustment of industrial structure. In recent years, the digital economy has been well integrated with the retail industry, financial industry, transportation industry and other industries. New models and new forms of business, such as online car-hailing, e-commerce, online finance and intelligent logistics, have been formed to promote the development of the service industry and promote the optimization and upgrading of the industrial structure [3].

The first impact of the digital economy on retail is the use of the Internet. Under the influence of the Internet, the retail industry has undergone great changes:

First, the Internet has greatly improved the convenience of retail terminals, especially the mobile Internet. Mobile Internet users can break through the limitation of time and place and use it anytime and anywhere through portable mobile terminals.

Second, the Internet has greatly enhanced the intelligence of retail terminals. The mobile terminal can record a large amount of information of users, which can be used to recommend corresponding services to users.

\section{7-2018 Three Industries Digital Economy Jobs (Unit: 10,000)}

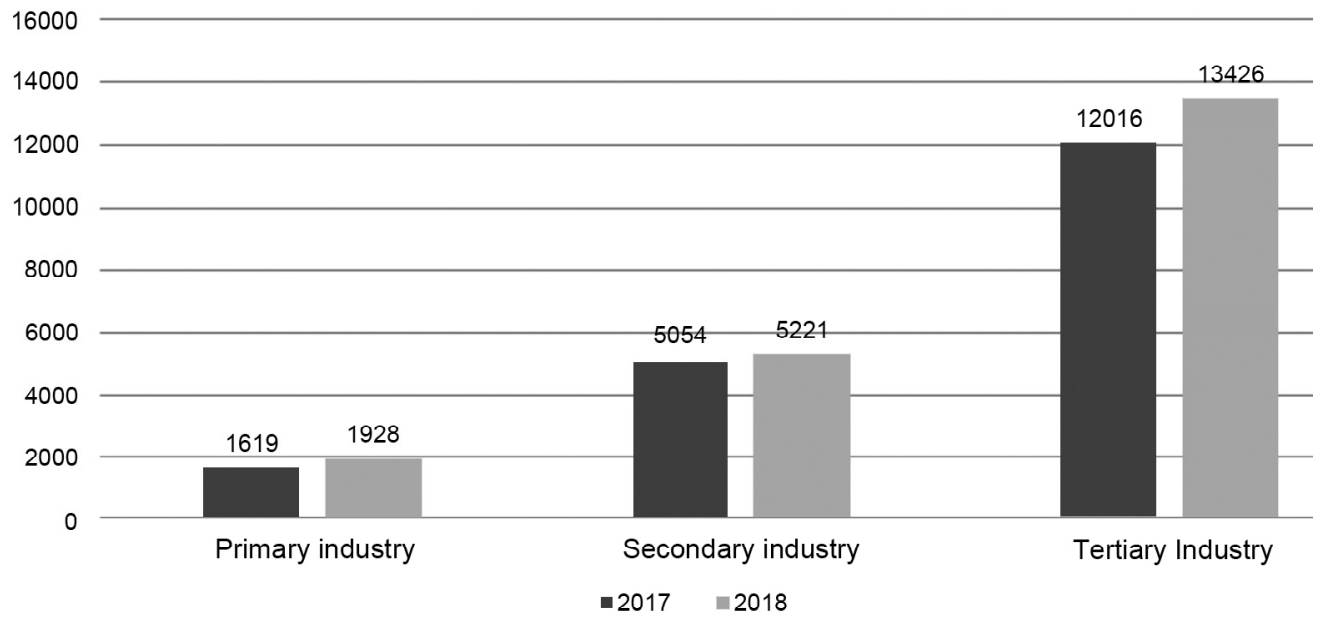

Figure 4. Three digital economy jobs in the industry in 2017-2018

Data from: China Academy of Information and Communications Technology. 
Third, the Internet has greatly enriched the diversity of retail services. In addition to the terminal carriers such as smartphones and tablet computers that are widely used at present, smartwatches, clothing and accessories will all become communication terminals in the future, with more diversified service terminals. [4]

Digital economy in the process of continuous development, the contribution to economic growth is also increasing. From 2014 to 2019 , the contribution rate of digital economy to economic growth was above $50 \%$. In 2019 , the contribution rate of digital economy to economic growth was $67.7 \%$. The contribution of digital economy to economic growth was higher than that of the three industries. As shown in figure 3.

In the three industries, according to the calculation data of China Academy of Information and Communications Technology, in 2018 , there were about 1,928 jobs related to the digital transformation of the primary industry, accounting for $9.6 \%$ of the total employment of the primary industry. The number of digitized jobs in the secondary industry was about 52.21 million, accounting for $23.7 \%$ of the total number of jobs in the secondary industry. The number of jobs in the digital transformation of the tertiary industry was about 134.26 million, accounting for $37.2 \%$ of the total number of people employed in the tertiary industry. Among them, the proportion of digital transformation jobs in the tertiary industry is the fastest. As shown in figure 4.

The second impact of the digital economy on retail is the widespread adoption of online retailing.

Online retail plays an increasingly prominent role in improving the quality and capacity of the retail market.

In 2018, China's online retail sales reached 906.5 billion yuan, an increase of more than three times that of 2014.

Among them, the retail sales of physical goods reached $5,480.6$ billion yuan, an increase of 1.9 times and an average annual growth of about $30 \%$.

In 2018, the growth rate of online retail sales of physical goods was 16.4 percentage points higher than that of total retail sales of consumer goods in the same period, accounting for 18.4 percent of total retail sales of consumer goods, 9.6 percentage points higher than that of 2014.

Online retail sales of physical goods contributed to the growth of total retail sales of consumer goods from $27 \%$ in 2014 to more than $45 \%$ in 2018 , significantly boosting the growth of total retail sales of consumer goods.

Driven by the rapid growth of emerging industries and the integrated development of online and offline businesses, China's retail industry continues to expand in scale and improve its operating efficiency.

In 2018, retail enterprises above designated size achieved sales of more than 12 trillion yuan, an increase of more than 26 percent over 2013.

The profit of main business exceeded 1.3 trillion yuan, with a growth rate of over $30 \%$. The gross profit margin of main business increased from $13.7 \%$ in 2013 to $14.5 \%$ in 2018.
Table 1. Indicators for measuring the industrial development level of digital economy

\begin{tabular}{|l|l} 
The secondary indicators & Index calculation method
\end{tabular}

Number of enterprises $\quad$ Number of industrial enterprises in digital economy

The proportion of fixed assets investment

in digital economy in total social investment

The proportion of the number of people employed in the digital economy in the total number of people employed

Total profits of digital economy industry

Digital economy industry R\&D

expenditure/GDP

\begin{tabular}{|l|l|}
\hline Technology patent & $\begin{array}{l}\text { Patent applications for electronic and } \\
\text { communications equipment manufacturing }\end{array}$ \\
\hline
\end{tabular}

\begin{tabular}{|l|l|}
\hline Technology patent & $\begin{array}{l}\text { Patent applications for electronic and } \\
\text { communications equipment manufacturing }\end{array}$
\end{tabular} industry

\begin{tabular}{|l|l|}
\hline Software developer & $\begin{array}{l}\text { The proportion of software r\&d personnel } \\
\text { in total employment }\end{array}$ \\
\hline Number of new product & Number of new product developments in
\end{tabular}

\begin{tabular}{|l|l|}
\hline Software developer & $\begin{array}{l}\text { The proportion of software r\&d personnel } \\
\text { in total employment }\end{array}$ \\
\hline Number of new product & Number of new product developments in
\end{tabular}

development projects the electronics and communications equipment manufacturing industry

\begin{tabular}{|l|l|}
\hline New product revenue & The proportion of new product income in \\
\hline
\end{tabular} the main business income

Technical application $\quad$ Revenue from information technology

\begin{tabular}{ll} 
level & services \\
\hline
\end{tabular}

\begin{tabular}{|l|l}
\hline Internet Development & Internet penetration
\end{tabular}

level

\begin{tabular}{|l|l|}
\hline Digital development level & E-commerce sales \\
\hline
\end{tabular}

With the support of national policies and measures such as tax cuts and fee reductions, corporate tax burdens have been reduced, and the debt-to-asset ratio of retail enterprises above designated size has dropped from $72.1 \%$ in 2013 to $69.6 \%$ in 2018 [5].

The organization of quality cash management is an important component of accounting and financial activities of a modern business entity. This component allows you to forecast cash flows, which can then be used as a basis for a campaign to strengthen the attraction of funds by economic entities, provides an important basis for the development and operation of a system for managing their availability and movement. Particular attention should be paid to fundraising, aggregation and disbursement, risk management, and the aids needed to monitor these systems [6].

Because our country industrial structure still exist problems, financial industry, wholesale and retail trade, transportation, warehousing and postal service center degree is high, the traditional service industries in the industrial system dominated, and information transmission, computer services and software industry, scientific research Gui and emerging technology services such as technical services ranked, industry internal structure level is low, is not conducive to economic development and social progress [7].

As a result, the digital economy cannot fully and effectively upgrade the whole industry, and the development level of the industry cannot be synchronized.

The core means of traditional retail business development lies in the channel, general retail enterprises through rapid of fline store layout, all over the country, by means of this rapid, bold type copy one, two, three, four levels of cities in China have a lot of different sizes of offline channels, before the e-commerce enterprises usher in explosive growth, through more offline retailing channels 
Table 2. The development of China's digital economy

\begin{tabular}{|l|l|}
\hline \multicolumn{1}{|c|}{ Outlook } & \multicolumn{1}{c|}{ Target } \\
\hline Infrastructure & $\begin{array}{l}\text { As the construction of new digital infrastructure } \\
\text { accelerates, 5G will become a key engine of the } \\
\text { digital economy }\end{array}$ \\
\hline Fusion application & $\begin{array}{l}\text { Sharing and manufacturing will become a new } \\
\text { highlight of development, and the industrial Internet } \\
\text { will be the key support }\end{array}$ \\
\hline $\begin{array}{l}\text { Enterprise } \\
\text { transformation }\end{array}$ & $\begin{array}{l}\text { Digital transformation is surging, and data } \\
\text { management capability will be an important } \\
\text { foundation }\end{array}$ \\
\hline $\begin{array}{l}\text { The government } \\
\text { transformation }\end{array}$ & $\begin{array}{l}\text { With the acceleration of digital government } \\
\text { construction, the big data decision support platform } \\
\text { will become a hot spot }\end{array}$ \\
\hline Regional development & $\begin{array}{l}\text { It has become a consensus to develop the digital } \\
\text { economy. The strong are getting stronger and } \\
\text { changing lanes to overtake cars will coexist for a long } \\
\text { time }\end{array}$ \\
\hline Digital governance & $\begin{array}{l}\text { Data governance continues to receive attention, and } \\
\text { blockchain technology is expected to be a } \\
\text { breakthrough }\end{array}$ \\
\hline
\end{tabular}

to enhance the enterprise the sales, and then highlight scale, improve business performance [8].

In the era of digital economy, however, the first element of competition in to the data, "data", after the enterprise transformation began to the user as the center, layout, and digital upgrade shop front end, PC, mobile terminal, family, and by adopting the channel strategy and the various channels of digital transformation, by comprehensive get all kinds of consumer data, can precipitate a lot of front-end data for the enterprise, for the enterprise management decision provides a large number of external consumer information, in order to provide related products to meet consumer demand, further to build the whole consumption scenarios, promote the whole channel integration as a whole.

\section{CONCLUSIONS AND PERSPECTIVES OF FURTHER RESEARCH}

Development Research Institute, its outlook on The development of China's digital economy is divided into six aspects: infrastructure, integrated application, enterprise transformation, government transformation, regional development and digital governance.

This is a major period of strategic opportunity for the development of the global digital economy, and the pace of development of the digital economy should continue to be accelerated. We will accelerate the process of making data elements valuable, focus on improving the basic capabilities of industries, push forward the digital transformation of the real economy, strengthen the governance capacity of the digital economy, and deepen the opening-up and cooperation of the digital economy.

The application and promotion of the Internet, especially the mobile Internet technology, should be strengthened to make it cover the retail industry completely.

And electric business enterprise should be encouraged to strengthen cooperation with the traditional retail enterprises, encourage large physical retail enterprises make full use of its own reputation and brand value, strengthen the own brand development and management, through reference to electric business enterprise management mode timely and moderately develop online sales channels and related business, relying on the development of own brand retail enterprise core competitiveness and competitive advantage, promote the development of traditional retailing and online retail fusion.

At the same time, relevant enterprises or platforms should be supported to extend their business to rural areas and international markets, so as to fully tap the development potential of digital economy, especially online consumption, in rural and international markets.

At present, the mainstream of economic development is digital economy. China has noticed this and made a lot of measures and attempts, especially in the retail industry. The development of digital economy has completely changed its industrial structure. Although these reforms will bring pain to many enterprises, they are a necessary step for development, and most enterprises in our country are doing well at present. But at the same time also found some shortcomings, such as the industry development is not synchronous and so on. It is hoped that the discussion of digital economy in this paper can provide some theoretical contributions for enterprises and other scholars, and make a contribution to the research in this field.

\section{References:}

1. Du, Q. (2019), "Research on Collaborative Governance of China's Digital Economy", Party School of the CPC Central Committee, vol. 1, pp. 36-46.

2. Liu, Z. (2018), "Research on Industrial Integration in the Context of digital Economy", University of International Business and Economics, vol. 1, pp. 28-34.

3. Zang, R. (2019), "Research on the Impact of industrial development of digital economy on the Optimization and upgrading of industrial structure", Beijing University of Posts and Telecommunications, vol. 1, pp. $9-11$.

4. Yu, J. (2017), "Research on the Impact of mobile Internet on the Efficiency of China's retail industry", Zhejiang Gongshang University, vol. 1, pp. 17-26.

5. Zhang, M. (2020), "Digitization promotes the highquality development of retail industry", China's National Conditions and National Strength, vol. 1, pp. 39-40.

6. Nazarenko, O. (2020), "Small cash fund" or corporate payment cards: accounting aspect, features of implementation", Zbirnyk tez dopovidei uchasnykiv XVIII Vseukrainskoi naukovoi konferentsii. Rozvytok systemy obliku, analizu ta audytu v Ukraini: teoriia, metodolohiia, orhanizatsiia [Collection of abstracts of the participants of the XVIII All-Ukrainian scientific conference. Development of accounting, analysis and audit in Ukraine: theory, methodology], National Academy of Statistics, Accounting and Audit, Kiev, Ukraine, pp. 79-84.

7. Zhang, J. (2018), "Research on O2O Model Transformation and Performance of retail Enterprises in the Digital Economy Era", Guangdong University of Finance and Economics, vol. 1, pp. 14-19.

8. Xie, L. and Zhuang, Y. (2019), "New Retail Mechanism in Internet and Digital Context - Enlightenment of Marx's Circulation Theory and Case Analysis", Finance and Trade Economics, vol. 1, pp. 1-3.

Стаття надійшла до редакиї 08.10.2020 p. 